\section{INSURANCE LAW - UNFAIR, UNCLEAR, ARCHAIC AND INACCESSIBLE?}

The English and Scottish Law Commissions are undertaking a joint review of insurance contract law.

Insurance law has frequently been criticised as outdated and potentially harsh to policyholders. Reports recommending reform were published by the Law Reform Committee in 1957, the English Law Commission in 1980, the National Consumer Council in 1997 and the British Insurance Law Association in 2002. These recommendations have not been implemented.

Since the English Law Commission's review in 1980, there have been significant developments in the regulation of the insurance market-place. There is now a statutory regulator - the Financial Services Authority - which issues conduct of business rules. Regulated firms are obliged to participate in a statutory complaints-resolution scheme, the Financial Ombudsman Service. Valuable as these developments are, we do not regard them as a complete solution. The rules do not address all the perceived ills of the law, and do not apply in their entirety to all classes of policyholder. Complaints can only be considered by the Financial Ombudsman Service if made by a consumer or a small business. Furthermore, the overall position looks increasingly incoherent, with fundamental issues being addressed differently by insurance contract law, the rules and guidance issued by the ombudsmen.

At the outset of our current review we decided that we would look at misrepresentation, non-disclosure and breach of warranty. We have also issued a Scoping Paper, seeking opinions as to which other areas deserve consideration. In early consultations it has been clear that there is wide support for reform, though inevitably there are differing opinions as to the nature and extent of any changes.

One of the main criticisms put to us is that the law is unfair, resulting in an imbalance of rights between insurer and policyholder. An applicant for insurance is, for example, obliged when applying for a policy to disclose all material facts - defined as those facts that would have an effect, not necessarily decisive, on the mind of a prudent insurer. It may not be easy for an applicant with little or no knowledge of insurance practice to meet this test. If there is a non-disclosure, which induces the contract, the insurer is entitled to avoid the policy from outset and reject any claim. As a matter of law this is so even if the nondisclosure is entirely innocent. The results can often be disproportionate. In our Scoping Paper we gave the example of a married couple who failed to mention the wife's partial loss of hearing when effecting a critical illness policy. Had the insurer been aware of the true facts, it would still have issued the policy, subject to an exclusion relating to her hearing. Sadly the wife subsequently died from a completely unconnected condition - leukaemia. The insurer discovered the non-disclosure and avoided the

$\begin{aligned} & \text { Articles } \\ & \text { The art of legislative drafting }\end{aligned}$
$\begin{aligned} & \text { Non-disclosure in insurance law: a more principled } \\ & \text { approach }\end{aligned}$
News

policy. One national newspaper recently reported that one in five critical illness claims are rejected, most for non-disclosure.

There are also areas where the law is unclear. Whatever the intention of those who drafted section 17 of the Marine Insurance Act 1906, it has been established that there is a post-contractual duty of good faith - with one member of the House of Lords commenting that the contrary is "past praying for". However, recent cases demonstrate the uncertainty surrounding the nature and extent of that duty - for example, whether it extends into litigation, the impact of fraudulent devices and whether interim payments can be recovered on the basis of subsequent fraud.

In some areas, the law is founded on eighteenth century statutes and cases, and no longer looks fit for the modern environment. Life insurers are limited in the policies they can offer by the provisions of the Life Assurance Act 1774 . Policies, for example, can be issued on the life of a spouse or civil partner, but not on the life of a cohabitant. Do such distinctions serve a useful purpose?

Finally, the rules governing the rights and obligations of the parties to an insurance policy are not easily accessible. Where consumers are concerned, for example, it is necessary to look in a range of sources, including statutes, cases, the rules issued by the Financial Services Authority, codes of practice issued by the Association of British Insurers and guidance published by the Financial Ombudsman Service.

As we now move into the next phase of the review, we intend to issue a short series of seminar papers, providing a focus for discussion on some of the key issues. This will be followed in 2007 by a formal consultation paper on perceived problems in the law, and potential solutions. Once consultation has closed we will prepare a final report and, if appropriate, a draft Bill.

We very much hope that those with an interest in this area will continue to give us the benefit of their experience and views throughout this period. Those wishing to follow the progress of the project can do so through our website at: http://www.lawcom.gov.uk/insurance_contract.htm

\section{Peter Tyldesley}

Law Commission 